\title{
薬剤師による採血や注射の実施等に対する病院薬剤師の潜在意識の探索
}

\author{
濃沼政美, ${ }^{*}, a$ 宮崎美子, $b$ 湯本哲郎, ${ }^{c}$ 佐藤 $\quad$ 透, ${ }^{d}$ 鈴木慎一郎, ${ }^{e}$ \\ 中島博史, ${ }^{f}$ 荒川基記, ${ }^{a}$ 小池勝也, ${ }^{a}$ 佐藤秀昭, ${ }^{g}$ 中村 $\quad$ 均 $a$
}

\section{Search for the Subconsciousness of Hospital Pharmacists on Their Practices of Blood Drawing or Injection, and etc.}

\author{
Masayoshi KoInuma, ${ }^{*}, a$ Yoshiko MiYAZAKI, ${ }^{b}$ Tetsuro YUmoto, ${ }^{c}$ Toru Sato, ${ }^{d}$ \\ Shinichiro Suzuki,${ }^{e}$ Hirohumi NaKaJima, ${ }^{f}$ Motoki ARAKawa, ${ }^{a}$ Katsuya KoIKe, ${ }^{a}$ \\ Hideaki SATO, ${ }^{g}$ and Hitoshi NAKAMURA ${ }^{a}$ \\ ${ }^{a}$ College of Pharmacy Nihon University, 7-7-1 Narashinodai, Funabashi, Chiba 274-8555, Japan, ${ }^{b}$ Department \\ of pharmacy Takatsu Central Hospital, 1-16-7 Mizonokuchi, Takatsu-ku, Kawasaki, Kanagawa 213-0001, \\ Japan, 'Department of pharmacy General Sagami Kosei Hospital, 3429 Koyama, Sagamihara, Kanagawa \\ 229-8555, Japan, 'Department of pharmacy Kikuna Memorial Hospital, 4-4-27 Kikuna, Kouhoku-ku, \\ Yokohama, Kanagawa 222-0011, Japan, e Department of pharmacy St. Marianna University School \\ of Medicine, Yokohama-City Seibu Hospital, 1197-1 Yasashicho, Asahi-ku, Yokohama, Kanagawa \\ 241-0811, Japan, ${ }^{f}$ Department of pharmacy Juntendo University Urayasu Hospital, 2-1-1 \\ Tomioka, Urayasu, Chiba 279-0021, Japan, and ${ }^{g}$ Department of pharmacy Ishinomaki \\ Municipal Hospital, 1-7-20 Minamihamacho, Ishinomaki, Miyagi 980-0835, Japan
}

(Received July 17, 2009; Accepted October 7, 2009; Published online October 9, 2009)

\begin{abstract}
The purpose of this study was to clarify the subconsciousness of hospital pharmacists regarding them practicing drip infusion or blood drawing for therapeutic drug monitoring (TDM), etc. We conducted a mail-in survey targeting 476 randomly-selected hospital pharmacists. In our survey sheet we presented our "hypothetical condition" i.e., "that medical practices such as drip infusion or blood drawing for TDM by hospital pharmacists be legally allowed" and we asked them 23 items about the pros and cons of this hypothetical condition and its influence on medical practice. Then, using factor analysis, we searched for the subconsciousness of hospital pharmacists from their answers to the 23 items. We then analyzed the causal association between the factors extracted from the survey and the pros and cons of the "hypothetical condition" using logistic regression analysis. $47.7 \%$ of respondents agreed to the "hypothetical condition". The results of this research provided 5 factors, consisting of "expectation of medical care and society", "temperament of pharmacists", "pharmacotherapy", "employment", and "medical team". We understood from the result of logistic regression analysis that hospital pharmacists subconsciously had two kinds of expectation, i.e., expectation about medical care and society, and about qualitative improvement of pharmacotherapy, as their background when they decided to agree to themselves practicing drip infusion or blood drawing for TDM, etc.
\end{abstract}

Key words — - hospital pharmacist; blood drawing; skill mix; questionnaire; exploratory data analysis

\section{背景 $\cdot$ 目的}

本研究は, 薬剤師による点滴静注や TDM 時の採 血等に対する病院薬剂師の潜在意識を明らかとする ことにより, スキルミックス等の薬剤師の職域に関

${ }^{a}$ 日本大学薬学部， ${ }^{b}$ 総合高津中央病院薬剤部， ${ }^{c}$ 総合相 模更生病院薬剤部, $d$ 菊名記念病院薬剤部, $e$ 聖マリア ンナ医科大学横浜市西部病院薬剤部, $f$ 順天堂大学医学 部附属浦安病院薬剂部, $g$ 石巻市立病院薬剤部

*e-mail: koinuma.masayoshi@nihon-u.ac.jp
する議論において，客観的情報として利用されるこ とを目的とする．現在，日本病院薬剤師会において 薬剂師によるバイタルサイン測定や TDM 時の採血 等の職域拡大に関する議論1,2) が展開されている.

筆者ら ${ }^{3}$ は，これらの議論に先駆け「薬剤師による 医療行為の可能性に関する研究」の一貫として, 新 たな病院薬剂師業務の方向性を探索するために, 看 護師に対する意識調查を実施し，看護師が薬剤師に 望む業務について調査を行つた。その結果，看護師 の $22 \%$ が TDM 時の採血, $13 \%$ が外用薬の塗布を 
薬剤師に求めており，特に役職看護師において高い 傾向が認められた。さらに，看護師が薬剤師に $\mathrm{TDM}$ 時の採血を求める要因についてデー夕解析を 行ったところ，第一には医療の質向上のため，つい で医療安全のためという意識構造が認められた。こ れらのことから，今後は薬剤師の職能拡大に関する 議論を行う上では, 看護師側からのニーズも一部踏 まえた上で検討していく必要性があると考えられた。

この研究結果を受け，筆者らは全国の病院薬郕師 を対象に,「病院薬剂師の職域拡大」に関連した計 7 項目の調査項目より構成される調査票に基づきア ンケート調査を行った。そこで，回答者の属性と注 射や採血の将来展望の関連性を明らかとすることを 目標とした調査項目（1-5）の解析を通じて, 約 4 割の病院薬剂師が薬剂師による採血や注射等の行為 が薬剤師の将来展望を明るくすると考えることを認 め, さらに, 多変量解析の結果, 「勤務薬剂師あた りの病床数が多い」,「勤務年数が長い」,「医薬品情 報業務を担当」の 3 要因の属性に該当するほど，採 血や注射等の行為が将来展望を明るくすると意識し ていることを確認した. ${ }^{4}$ また，この意識には本人 の職務満足度と患者からの信頼という 2 項目の心理 的属性との関連性が認められた。

そこで本稿では，薬剤師による採血や注射の実施 等に対する病院薬剤師の潜在意識を探索することを 目標とした調査項目 (6)の解析を通じて, 薬郕師に よる点滴静脈注射や TDM 時の採血等の実施が，仮 に現実となった場合の賛否と，これらの実施が社会 や医療に及ぼす影響についての意識との関連性につ いて解明した。

\section{方法}

\section{1. 対象と調查方法 日本病院薬剂師会会員名} 簿（薬事新報社） 2007 を用い，全国 47 都道府県， 計 476 名の薬剂師を会員名簿 1 ページから 1 名を対 象に無作為に抽出した。対象者には，直接個人宛に 調査票と返信用封筒を郵送した。また，調査期間は 2007 年 2 月 20 日から 3 月 31 日とした.

2. プライバシーへの配慮調査票はすべて無 記名とし，本調査で入手した個別情報は，すべて統 計数字として表し，個人のプライバシーに係わる情 報が公開されることはなく, 研究以外の目的では使 用されない旨を明記した。
3. 調査票配布した調査票は，回答者属性， 薬剂師の将来展望, 薬剂師による採血や注射の実施 等に対する意識などを含む計 7 項目で構成されてい る，前報において，回答者の属性と注射や採血の将 来展望の関連性を明らかとすることを目標に調査項 目（1-5）を用いた解析を行った。本項では以下に 示す調査項目 (6)を用いた解析を行った.

3-1. 点滴静脈注射（以下, 点滴静注）や TDM 時の採血等の行為に対する架空の設定内容（以下, 設定内容）の提示 調査票には，「薬剤師による 点滴静注や TDM 時の採血等の行為, 外用剂の塗布 等の行為が法的に認められた」，とする “設定内容” を提示し（Fig. 1)，これに対する回答者の見解に ついて設問した。

\section{3-2. 調査項目}

A）提示した “設定内容”に対する賛否（以下， 採血等に対する賛否)

設問：「仮に薬剤師に点滴静注や外用剤の 塗布など薬剤に関連する医療行為 が，認められることは好ましい事 であると思いますか?」

測定尺度：全く思わない〜非常に思う（6 水準)

B）“設定内容”の現実化によって，医療分野 への影響が想定される項目に対する回答者意 識（以下，影響項目）

設問：「仮に薬剂師に点滴静注や外用剂の 塗布など薬剤に関連する医療行為 が認められた際，現行の制度に比 較してどのような影響が生じると 予測しますか?」

測定尺度：Visual analogue scale $[10 \mathrm{~cm}$ ス ケールにおいて，悪化（又は低下） を一 5 , 現行を 0 , 向上（又は増加） を+5 として，書き入れられた線の ポイントの数值を定規で測定して数 值化］により，薬物療法の質や効率 性，病院薬剤師の資質，就労条件な どの 23 項目について，回答者意識 の測定を行った. (Fig. 2) そして, 測定したスコアを項目毎に平均値と 標準偏差を算出した.

4. データ解析 本研究におけるデー夕解析目 
以下の文章は架空の内容です。しかしこの質問に答えていただくことにより、未来の薬郕師 の新たな方向性や、大学での薬绪師教育のあり方について検討することが出来ます。このこと をこ理解いただいた上で、あくまで架空であることを前提に質問にお答え下さい。

平成○○年、医療の高度化やリスクマネジメントなどの医療ニーズの変化や、大学での藥 剂師教育の变革により、点滴静脈注射や筋肉注射、外用剂塗布、薬物血中濃度測定時の採 血など、薬剤に関連する医療行為に限定した上で、医師の同意のもと、これらの医療行為 を薬威師が行えることが法案で認められました。その結果、藥用師法が改訂され、以下に 示す条文が加えられました。

【改訂薬棛師法】（架空の内容です）

A.「薬郕師は、医師の同意を得た場合を除いては、調剤した薬剤の投与を行なってはなら

ない。」

B.「薬郕師は、医師の同意を得た場合を除いては、調剮上必要とされる採血を行なっては

ならない。」

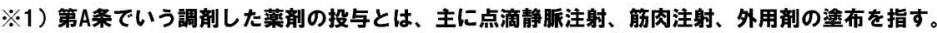

※2) 第B条でいう調郕上必要とされる採血とは、主に薬物血中濃度測定時における採血を指す。

$※ 3)$ 第A条、第B条でいう医師の同意を得た場合とは、原則として書面による同意を指す。ただし、緊急時など 書面により同意を得られない場合は、䕱においてもその限りではない。

ただし、認められる際における薬郕師の医療行為（賟郕に限定した）の教育・技術レベルは、 現行の看護師と同程度である事と仮定します。

(調查票より引用)

Fig. 1. Hypothetical Requirements on Questionnaire Involving Blood Drawing by a Pharmacist

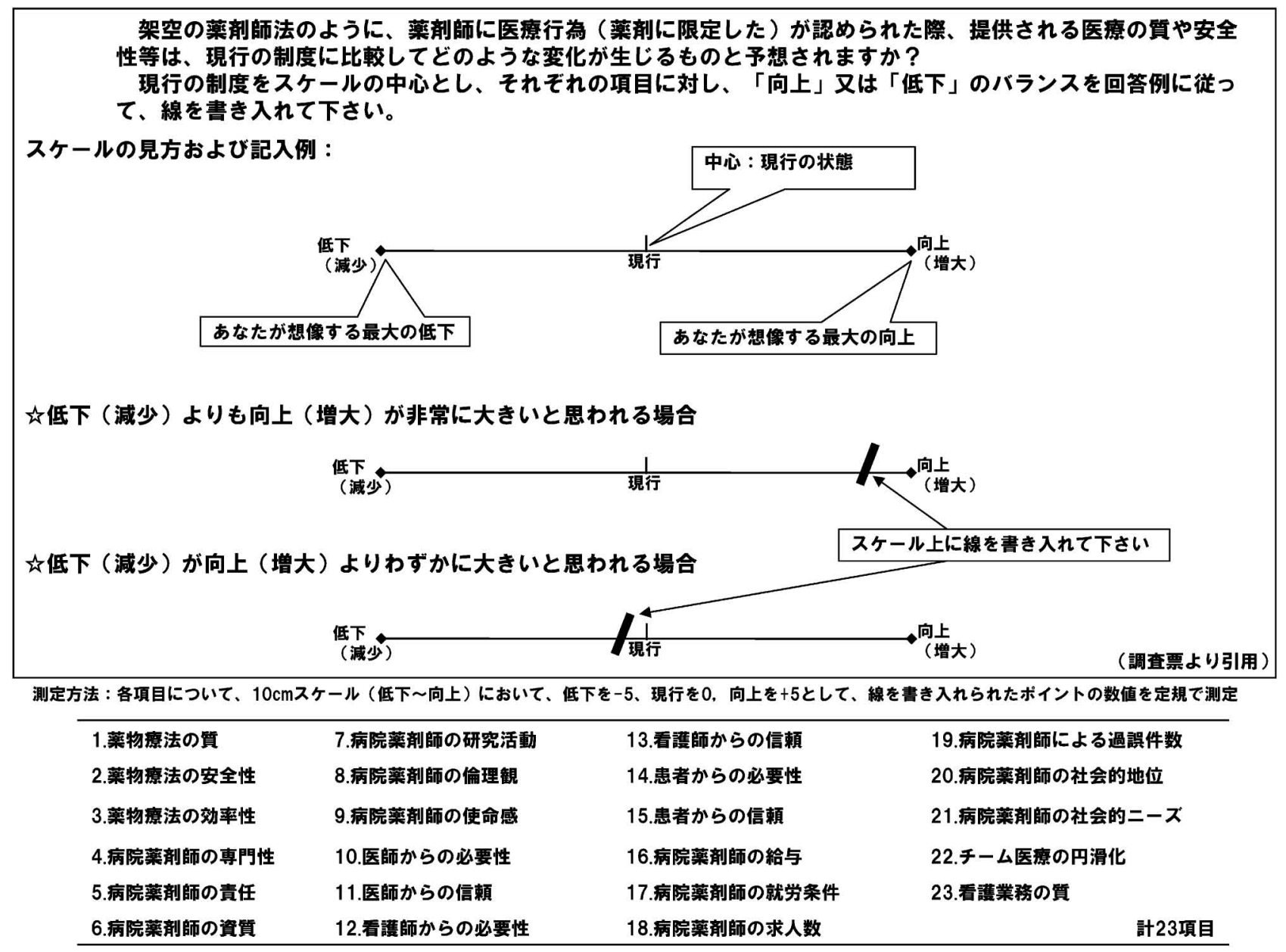

Fig. 2. Measurement Method of the Scale and Measured Effect Points 
標を「採血等に対する賛否に影響する要因の解明」 とし，以下の方法に従い探索的デー夕解析を試みた.

4-1. 解析フレームワークの構築 解析目標を 達成するために解析フレームワークを構築し，レべ ルに従いデータ解析を行つた。（Fig. 3)

4-2. 採血等に対する賛否と影響項目との関連性 採血等に対する賛否 6 水準のデータを反対群・賛 成群の 2 水準データに変換した． 2 水準に変換され たデー夕を目的変数，23 項目の影響項目（スコア： $-5 \sim+5 ）$ を説明変数に，一元配置分散分析を行つ た．有意差検定は，説明変数の全項目がパラメトリ ック検定の前提条件 (正規性は Shapiro-Wilk 検定, 等分散性は，O’Brienの検定）を満たした場合は, $t$ 検定，これらを満たさなかつた場合はWilcoxon 順位和検定とした。なお，2 水準間の有意差が 0.05 未満であった影響項目を，「賛否に有意に関連する 影響項目」と定義した。なお， 6 水準データを 2 水 準データへ変換した理由は，6 水準データでは引き 続き行う多重ロジスティック回帰分析において，順 序ロジスティックモデルへ，当てはめることとな り，最終的な結果の解釈がし難いものと判断したた めである。

4-3. 累積寄与率の算出及び因子分析における因 子回転数の決定（Varimax 回転）一般に多重回 帰分析を行う際，代入する説明変数間に強い相関が
ある場合，多重共線性が生じ，正確な回帰式を導き 出すことが困難とされる。そこで本解析では，「賛 否に関連性の高い影響項目」を因子分析法によりグ ループ化した。 因子分析の方法は，相関係数行列か ら主成分分析を実施し，累積寄与率が 7 割を超えた 時点までの主成分数を基準に，Varimax 回転におけ る因子回転数を設定した.

4-4. 「賛否に有意に関連する影響項目」のグルー プ形成，及びグループに基づく因子の命名 因子 分析を実施し, Varimax 回転後の最終的な因子パ ターンから，因子毎に賛否が有意に関連する影響項 目についてグループ形成を行つた。 この因子を構成 するグループを以下，項目グループとする．項目グ ループの内容から，それぞれの因子について命名し た.

4-5. 項目グループに基づいた新たな変数の産生 多重ロジスティック回帰分析に当てはめるための 説明変数には，「賛否に有意に関連する影響項目」 の回答者のスコアから因子毎に項目グループの平均 值を求め，これを新たな変数（以下，項目平均スコ ア）とした。 なお，項目平均スコアは，以下の計算 式により算出した.

- 項目平均スコア

=項目グループ内の「賛否に有意に関連する影響 項目」の回答者スコアの合計／項目グループに

解析目標：「採血等に対する賛否に影響する要因の解明 」

\begin{tabular}{|c|c|c|}
\hline レヘル & 目的 & 解析 \\
\hline 1 & $\begin{array}{c}\text { 採血等に対する替否（6水準）を反対・賛成の2水準データに単純化 } \\
\downarrow\end{array}$ & 水準数変換 \\
\hline II & $\begin{array}{c}\text { 採血等に対する賛否（2水準）と23項目の影響愐目（スコア：-5 +5）との関連性 } \\
\downarrow\end{array}$ & 一元配置分散分析 \\
\hline III & $\begin{array}{c}\text { 賛否に有意 }(p<0.05) \text { に関連する影響項目間の相関係数から累清寄与率の算出 } \\
\text { 因子分析の回転数設定 }(\text { Varimax回転 })\end{array}$ & 主成分分析 \\
\hline & $\downarrow$ & \\
\hline IV & 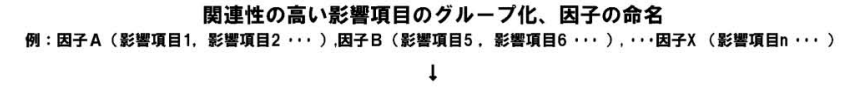 & 因子分析 \\
\hline v & 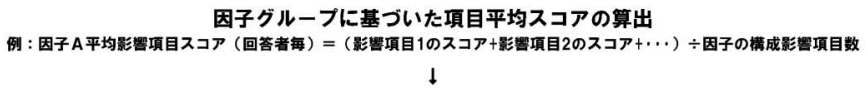 & 平均値算出 \\
\hline VI & $\begin{array}{c}\text { 目的変数を採血等に対する琴否（2水準）、説明変数を因子スコアとした } \\
\text { 多重ロジスティック回郒モデルの作成 }\end{array}$ & $\begin{array}{l}\text { ロジスティック } \\
\text { 回帰分析 }\end{array}$ \\
\hline & $\downarrow$ & \\
\hline VII & $\begin{array}{c}\text { 回帰モデルの妥当性診断 } \\
\text { モデルのF検定・Lack Of Fit・パラメータ尤度比険定 } \\
\downarrow\end{array}$ & 統計的検定 \\
\hline VIII & モデルからデータの推定 & $\begin{array}{l}\text { 偏回帰係数 } \\
\text { Odds比算出 }\end{array}$ \\
\hline
\end{tabular}

Fig. 3. Framework for Analysis Target 
おける項目数

4-6. 採血等に対する賛否に影響する要因の解明 採血等に対する賛否 (2 水準) を目的変数，因子 数分の項目平均スコアを説明変数として, 最尤推定 法に基づきロジスティックモデルへの当てはめを行 つた。なお，モデルに加える説明変数の選択方法 は，変数削除の基準 $p$ 值を $p>0.1 （$ 尤度比検定） としたステップワイズ変数減少法とした。また，回 帰モデルの妥当性については，自由度調整 $\mathrm{R}^{2}$, Lack of Fit (以下, LOF), Receiver Operating Characteristic curve（以下，ROC）により，回帰診断を 行った。そして，最終的に作成した回帰式の偏回帰 係数及び Odds 比より，採血等に対する賛否に影響 する要因の解明を試みた。

4-7. ソフトウェア 有意差検定及び回帰モデ ル作成には，JMP ${ }^{\circledR} 7.02$ (SAS Institute）を使用し た.

\section{結果}

1. 集計 調査票の回収率は $37.0 \%(176 / 476)$ であった。採血等に対する賛否について 6 水準での 回答結果は（未回答 2 件除く），全く思わない 18.9 \%，おおむね思わない $12.1 \%$ ，どちらかというと 思わない $20.7 \%$ ，どちらかというと思う $20.1 \%$ ， おおむね思う $21.3 \%$ ，非常に思う $6.9 \%$ であった。 これを 2 水準に変換した結果，思わない（反対） $51.8 \%$ ，思う（賛成） $48.2 \%$ となった。（Fig. 4） “設定内容”の現実化によって影響する項目として 薬物療法の質や効率性, 病院薬剤師の資質, 就労条 件など 23 種の項目について回答者意識の測定を行 った結果，平均值は，23 項目中 22 項目において現 行より向上（又は増大）する結果となった，唯一, 低下（又は減少）となった項目は，就労条件であっ た（全項目未回答 2 件除 $<） 。$ 影響項目の回答者久 コアにおける平均値と標準偏差の関係を Fig. 5 に 示す.

2. データ解析 採血等に対する賛成群と反対 群との間で，各影響項目の平均スコアを比較した結 果, 23 項目中, 病院薬剤師による過誤件数を除く 22 項目において，賛否の 2 群間に有意差が認めら れた。この 22 項目を「賛否に有意に関連する影響 項目」とし，因子分析を試みた。相関係数行列から 主成分分析を実施したところ，第 5 主成分までの累

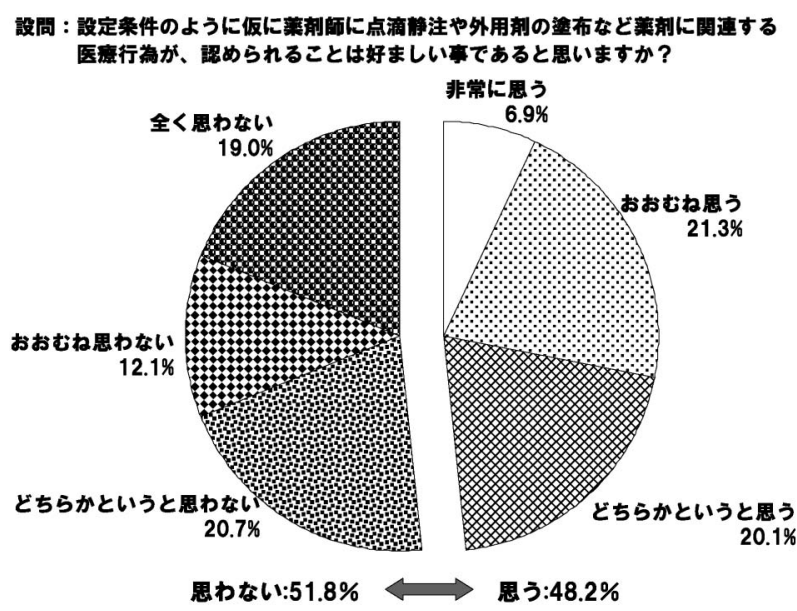

Fig. 4. Ratio of Responses of Hospital Pharmacists on Their Practicing Blood Drawing or Injection, etc.

積寄与率が標本全体の分散の $71.00 \%$ を占めた. （Fig. 6）そこで，因子回転数を 5 回転に設定し Varimax 回転による因子回転を行った。その結果, 因子パターンから因子 1 は，相関係数の高い順に, 医師からの必要性，看護師からの信頼，医師からの 信頼，患者からの信頼，看護師からの必要性，患者 からの必要性，社会的ニーズ，社会的地位の 8 項目 による項目グループが形成された。同様に，因子 2 は, 薬剤師の使命感, 専門性, 研究活動, 倫理観, 責任，資質の 6 項目，因子 3 は，薬物療法の安全 性, 効率性, 質の 3 項目, 因子 4 は, 薬剤師の就労 条件, 給与, 求人数の 3 項目, 因子 5 は, チーム医 療，看護業務の質の 2 項目による項目グループが形 成された。これらの項目グループの内容から，それ ぞれの因子を因子分析法に従い命名したところ，因 子 1 は医療・社会の期待，因子 2 は薬剤師の質，因 子 3 は薬物療法，因子 4 は雇用，因子 5 は医療チー ムとなった（Table 1).

採血等に対する賛否 (2 水準) を目的変数，項目 平均スコアを説明変数に，ステップワイズ回帰（変 数減少法）を行い, 多重ロジスティック回帰モデル への当てはめを行った．ステップワイズ回帰によ り, 目的変数との因果関係の希薄な順に, 因子 2 (薬剂師の質), 因子 4 (雇用), 因子 5 (医療チーム) が削除され，最終的に因子 1 (医療・社会の期待) と因子 3 (薬物療法) を変数としたモデルが作成さ れた。なお，モデル式におけるパラメータ推定值 は，因子 1 が 0.60 , 因子 2 が 0.67 であり，目的変 


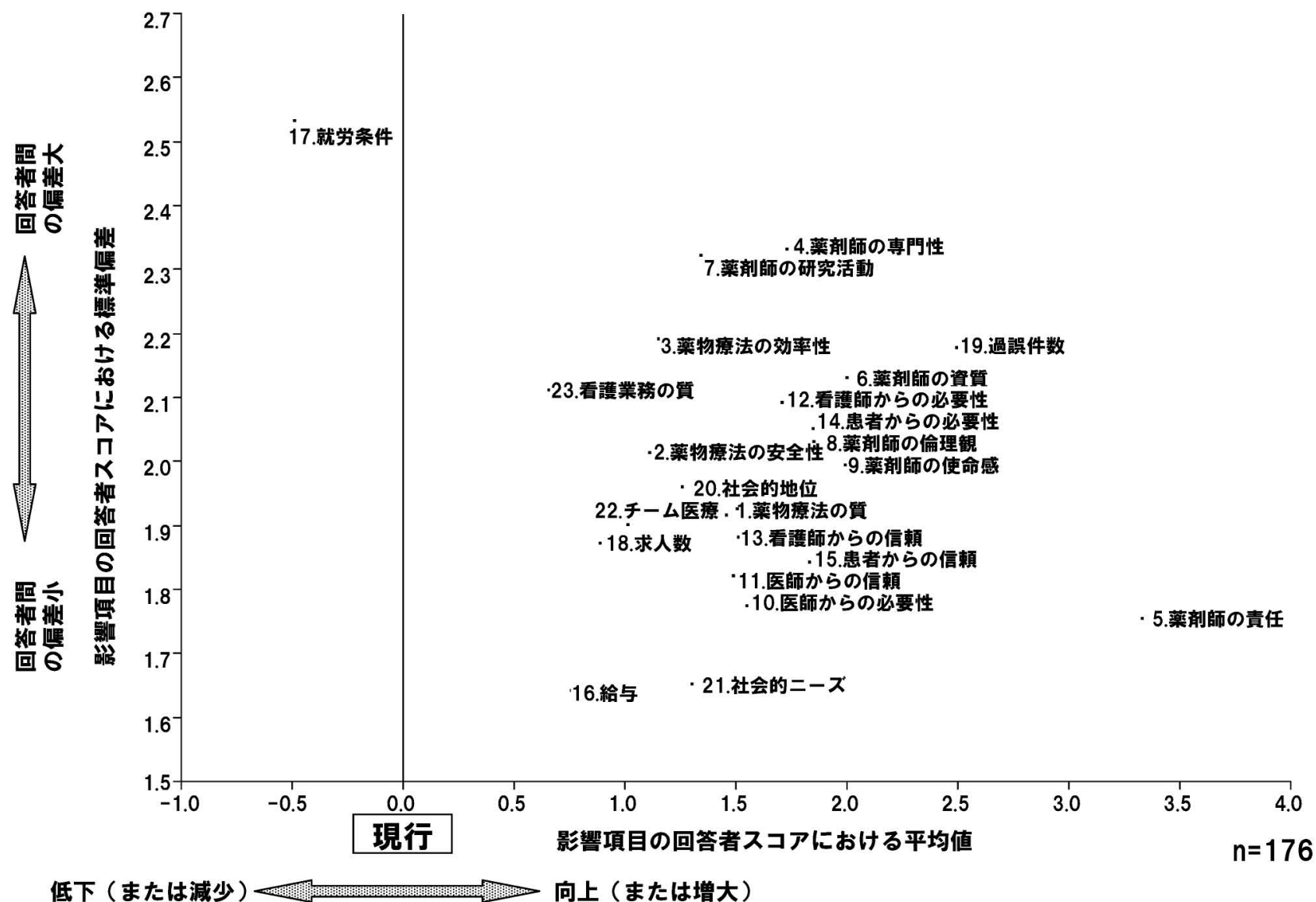

Fig. 5. Relation between Mean and Standard Deviation in the Respondent Score on the Effect Points

\begin{tabular}{|c|c|c|c|}
\hline 主成分 & 固有値 & 奇与事 & 累掅奇与事 \\
\hline 1 & 10.15 & 46.13 & 46.13 \\
\hline 2 & 1.95 & 8.85 & 54.98 \\
\hline 3 & 1.44 & 6.55 & 61.53 \\
\hline 4 & 1.17 & 5.30 & 66.83 \\
\hline 5 & 0.92 & 4.17 & 71.00 \\
\hline 6 & 0.85 & 3.87 & 74.87 \\
\hline 7 & 0.71 & 3.24 & 78.11 \\
\hline 8 & 0.63 & 2.88 & 80.99 \\
\hline 9 & 0.60 & 2.71 & 83.70 \\
\hline 10 & 0.50 & 2.29 & 85.99 \\
\hline 11 & 0.46 & 2.11 & 88.10 \\
\hline 12 & 0.43 & 1.95 & 90.04 \\
\hline 13 & 0.39 & 1.77 & 91.81 \\
\hline 14 & 0.32 & 1.46 & 93.28 \\
\hline 15 & 0.30 & 1.37 & 94.64 \\
\hline 16 & 0.28 & 1.28 & 95.92 \\
\hline 17 & 0.22 & 0.98 & 96.90 \\
\hline 18 & 0.19 & 0.88 & 97.78 \\
\hline 19 & 0.18 & 0.82 & 98.60 \\
\hline 20 & 0.14 & 0.66 & 99.26 \\
\hline 21 & 0.12 & 0.53 & 99.79 \\
\hline 22 & 0.05 & 0.21 & 100.00 \\
\hline
\end{tabular}

累皘寄与率が7割を超えた 時点までの主成分数を基準<smiles>C1=CC=C1</smiles>

第5主成分までで、標本全体 の分散の71.00\%を占める

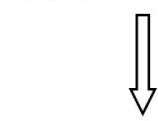

因子回転数を5回転に設定 (Varimax回転)

Fig. 6. Principal Component Analysis of "the Effect Point Associated with the Vote Significance" -Setting the Number of Factor Rotations Based on Cumulative Contribution Ratio

数に対しこれらは同程度の因果関係であることが確 認された。 また，単位オッズ比から $-5 \sim+5$ のス ケールにおいて，スコアが 1 増えるに従い，因子 1

は 1.82 倍, 因子 3 は 1.96 倍の比率で, 賛成する回 答者のオッズが増すことが示された.（Fig. 7)

モデル診断の結果, 自由度調整 $\mathrm{R}^{2}$ は, 0.31 を示 し，要因探索を目的とした回帰式としては，妥当な 值であると考えた．LOFによる $p$ 值が有意でなか つたことから, それ以外の説明変数, 又は, べき乗 項の変数を加える必要性の低いことが確認された。

また, 推定の感度及び特異度の関連性を示す指標で ある ROC 曲線下の領域の值は 0.85 を示し, 1 に近 似していることからモデルの推定精度は高いもので あった．これらの回帰診断の結果から，モデル式の 妥当性は確保されており，ここから得られたパラ メータによるデータ推定は妥当であると考えた.

$$
\text { 考察 }
$$

現時点における病院薬凨師の採血等に関する “設 定内容”に対する賛否は，ほぼ均等に二分されてい た。これは, 前報4)において約 4 割の病院薬剂師が 薬剂師による採血や注射等の行為が薬剤師の将来展 望を明るくするとした割合と近似しており，この理 
Table 1. Factor Analysis of "the Effect Point Associated with the Vote Significance"-Factor Pattern of the Coefficient of Correlation after Varimax Rotation

\begin{tabular}{|c|c|c|c|c|c|c|}
\hline \multicolumn{2}{|c|}{ 因子番号 } & 因子 1 & 因子 2 & 因子 3 & 因子 4 & 因子 5 \\
\hline \multicolumn{2}{|c|}{$\begin{array}{c}\text { 因子の命名 } \\
\text { (項目グループの解釈) }\end{array}$} & 医療・社会の期待 & 薬剂師の質 & 薬物療法 & 雇 用 & 医療チーム \\
\hline \multirow{22}{*}{$\begin{array}{l}\text { 賛 } \\
\text { 䂞 } \\
\text { 有 } \\
\text { 意 } \\
\text { に関 } \\
\text { 連 } \\
\text { す } \\
\text { 影 } \\
\text { 響 } \\
\text { 目 }\end{array}$} & 10. 医師からの必要性 & 0.82 & 0.35 & 0.14 & 0.18 & 0.02 \\
\hline & 13. 看護師からの信頼 & 0.80 & 0.28 & 0.12 & 0.12 & 0.21 \\
\hline & 11. 医師からの信頼 & 0.76 & 0.40 & 0.25 & 0.15 & 0.08 \\
\hline & 15. 患者からの信頼 & 0.76 & 0.40 & 0.19 & 0.12 & 0.06 \\
\hline & 12. 看護師からの必要性 & 0.71 & 0.15 & -0.05 & 0.10 & 0.31 \\
\hline & 14. 患者からの必要性 & 0.70 & 0.40 & 0.14 & 0.09 & 0.05 \\
\hline & 21. 社会的ニーズ & 0.69 & 0.11 & 0.39 & 0.35 & 0.20 \\
\hline & 20. 社会的地位 & 0.66 & 0.14 & 0.29 & 0.40 & 0.11 \\
\hline & 9. 薬剂師の使命感 & 0.42 & 0.74 & 0.04 & 0.20 & 0.04 \\
\hline & 4. 薬剂師の専門性 & 0.31 & 0.65 & 0.27 & -0.08 & 0.26 \\
\hline & 7. 薬剂師の研究活動 & 0.29 & 0.52 & 0.23 & -0.07 & 0.17 \\
\hline & 8. 薬剤師の倫理観 & 0.24 & 0.72 & 0.14 & 0.20 & 0.19 \\
\hline & 5. 薬剤師の責任 & 0.20 & 0.68 & 0.14 & 0.12 & -0.05 \\
\hline & 6. 薬剂師の資質 & 0.16 & 0.76 & 0.28 & 0.09 & 0.12 \\
\hline & 2. 薬物療法の安全性 & 0.11 & 0.23 & 0.81 & 0.16 & 0.23 \\
\hline & 3. 薬物療法の効率性 & 0.30 & 0.44 & 0.55 & -0.05 & 0.09 \\
\hline & 1. 薬物療法の質 & 0.21 & 0.28 & 0.82 & 0.10 & -0.01 \\
\hline & 17. 薬剂師の就労条件 & -0.01 & 0.13 & -0.07 & 0.75 & 0.04 \\
\hline & 16. 薬剂師の給与 & 0.36 & 0.02 & 0.14 & 0.74 & 0.06 \\
\hline & 18. 薬剂師の求人数 & 0.24 & 0.08 & 0.18 & 0.73 & 0.01 \\
\hline & 22. チーム医療 & 0.42 & 0.34 & 0.26 & 0.05 & 0.57 \\
\hline & 23. 看護業務の質 & 0.18 & 0.13 & 0.10 & 0.08 & 0.89 \\
\hline & $\begin{array}{l}\text { 因子を構成する項目数 } \\
\text { 目グルーフおける項目数） }\end{array}$ & 8 & 6 & 3 & 3 & 2 \\
\hline
\end{tabular}

由は両研究における対象が一致していること，ま た，同一の調査票内での調査であったことが近似し た理由とも考えられる。

採血等に対する行為の現実化によって影響すると 考えられた項目の平均值は，就労条件を除き，すべ ての項目において向上若しくは増加するとの考えが 認められた。しかし，過誤件数については増加する との考えが示されたことから，就労条件及び過誤件 数は, これら行為の現実化によって, 悪影響が出る ものとしてとらえられていると考えられた。

採血等に対する賛成群と反対群との間で, 各影響 項目の平均スコアを比較し，影響項目との間で有意
に関連性が高い項目について因子分析を試みた結 果，影響項目を 5 つの因子に分類することができた （因子 1 : 医療・社会の期待, 因子 2 : 薬剤師の質, 因子 3: 薬物療法, 因子 4:雇用, 因子 5: 医療 チーム)。採血等に対する賛否に影響を与えている 因子を探索するために 5 因子（正確には，因子内の 影響項目の平均值）を説明变数としてロジスティッ ク回帰分析を行った。その結果，賛否に対して有意 に関連した項目は，「医療・社会の期待」と「薬物 療法」の 2 要因のみであった。このことから, 薬剤 師が採血や点滴静注等の行為に賛成する要因は，あ くまでも薬剤師自身の質や雇用等の向上のためでは 


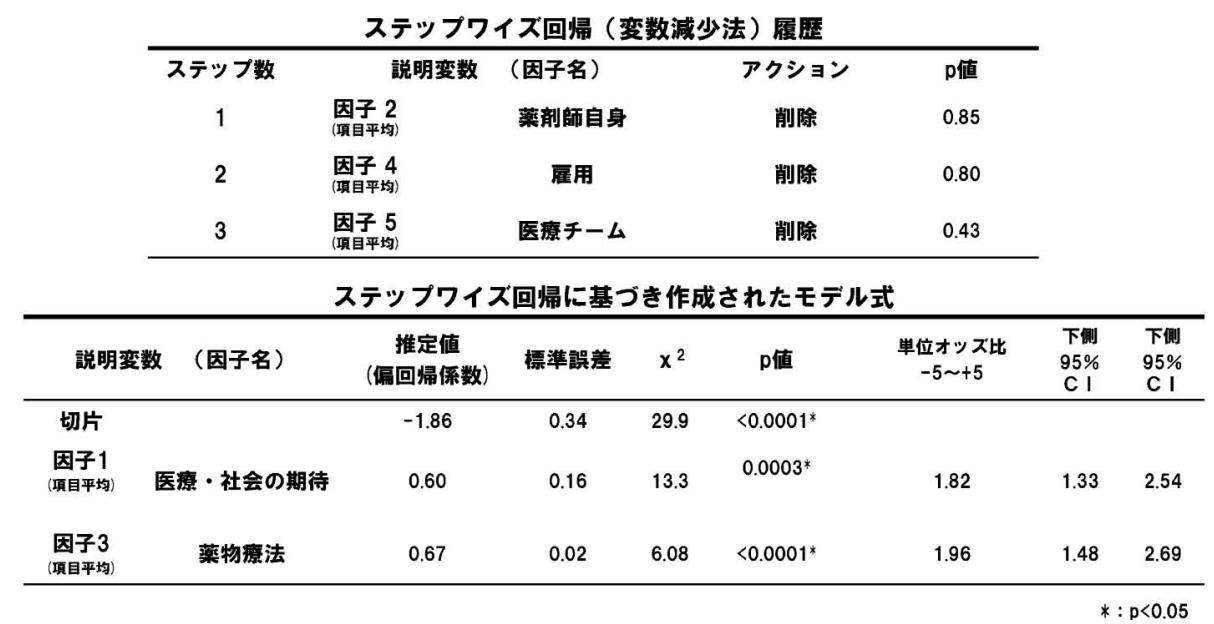

予测式 : $\ln (p /(1-p))=0.60 \times$ 因子 1 (項目平均 $)+0.67 \times$ 因子 3 (項目平均 $)-1.86$

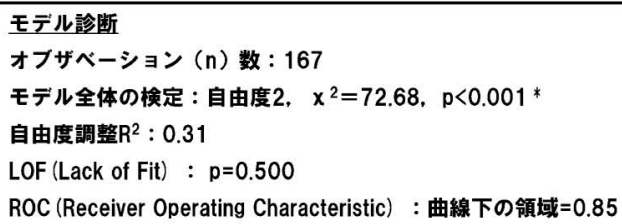

Fig. 7. History of Stepwise Regression and the Logistic Regression Model

なく，「医療・社会の期待に応えるため」，また， 「薬物療法の質を向上させるため」という 2 つの期 待が潜在意識に存在していたものと考えられた.

徳永 $ら^{5)}$ は, 薬剤師の職能拡大に対する病院薬剤 師の意識に及ぼす因子の探索を行った。これによれ ば，職能拡大の必要性が認められた項目としては, 身体状態の測定や救命救急の教育指導等の，従来か らの薬剤師業務の延長業務であったとしており，特 に点滴静注や採血等の行為までの職能拡大について は，意識の中に認められなかった。しかし，本稿の 解析結果においては，点滴静注や採血等の実施によ り，薬剤師が医療・社会の期待に応えることができ る，また，薬物療法の質を向上させることができる と意識していることが認められた。この研究結果を 一概に比較することはできないが，これらの違い は，両研究の調査対象における影響が考えられる. 本研究においては, 対象者を一般職から管理職まで の, 現職の病院薬剂師を偏りなく無作為抽出してい るが，前述の報告では，薬局長や薬剤部長などの管 理職が対象であったことから，比較的既定的な意見 が集約されたためと考えられる.

現在, 日本病院薬剤師会や日本学術会議薬学委員 会6)では，バイタルサインの測定や TDM の採血等 に対して薬剤師の職能拡大の議論を広げようとして
いる. 本研究により, 現職病院薬剂師の点滴静注や TDM 時の採血等の実施に対する潜在的な意識を把 握できたことは，薬剤師の新たな業務展開について 議論する上で極めて重要な知見であると考える.

今後, 新たな薬剤師業務として, 採血や点滴静注 等の行為を実施するためには，法的根拠を始め他職 種との関連や教育など数多くの解決すべき点が存在 する。しかし，それ以前にわれわれ，薬剤師同士の 見解を統一することが極めて重要な課題であろう. 本結果が，薬剤師の職域拡大に関する議論におい て，客観的情報として利用されることを期待する。

謝辞 アンケート調查に協力して頂きました日 本病院薬剤師会会員の先生方に深くお礼申し上げま す。また，本研究を実施するにあたり統計解析手法 に関して多大なるご助言を頂きました元東京理科大 学理工学部教授 芳賀敏朗先生に深くお礼申し上げ ます。

\section{REFERENCES}

1) YAKUJI NIPPO, July 30th 2008.

2) Horiuchi R., JJSHP, 44, 477 (2008).

3) Koinuma M., Hoshino S., Koike K., Nakamura H., Jpn. J. Soc. Pharm., 27, 17-26 
(2009) .

4) Koinuma M., Imai Y., Kanda M., Koike K., Miyazaki Y., Sato T., Nakamura H., Yakugaku Zasshi, 129, 887-896 (2009) .

5) Tokunaga J., Koinuma M., Takamura N.,
Ogata K., Yoshida Y., Yamamoto R., Nakamura H., Jpn. J. Pharm. Health Care Sci., 35, 417-422 (2009).

6) 〈http://www.scj.go.jp/ja/info/kohyo/pdf/ kohyo-20-t62-12.pdf $\rangle$, cited 16 March, 2009. 